\title{
Rho Proteins Play a Critical Role in Cell Migration during the Early Phase of Mucosal Restitution
}

\author{
Marinilce F. Santos, ${ }^{\star}$ Shirley A. McCormack, ${ }^{*}$ Zhong Guo, ${ }^{\star}$ Juraj Okolicany, ${ }^{\star}$ Yi Zheng, ${ }^{\ddagger}$ Leonard R. Johnson, ${ }^{*}$ \\ and Gabor Tigyi* \\ $*$ Department of Physiology and Biophysics, and ${ }^{\ddagger}$ Department of Biochemistry, University of Tennessee, College of Medicine, Memphis, \\ Tennessee 38163
}

\begin{abstract}
In the intestine, several growth factors stimulate migration of epithelial cells, contributing to the maintenance of tissue integrity. The Ras-like GTPase Rho regulates a signal transduction pathway linking growth factor receptors to the formation of actin stress fibers and focal adhesions, presumed to be important for motility. Using an in vitro wound-induced migration assay, we have examined the role of Rho GTPases in the migration of IEC-6 and Caco- 2 cells, and provide evidence that the Rho GTPases play an essential role in the initial phase of mucosal wound healing. Treatment of the cells with Clostridium difficile toxins A and B, inhibitors of the Rho family GTPases inhibited migration in a dose-dependent fashion. Microinjection of the inhibitory exchange factor Rhoguanine nucleotide dissociation inhibitor (GDI), or Clostridium botulinum C3 ADP-ribosyl transferase (C3) toxin, a Rho-ADP-ribosylating exoenzyme, potently inhibited migration. Microinjection of RhoT19N, a dominant negative form of RhoA, or in vitro ADP-ribosylated RhoA impaired the ability of cells to migrate. Rho-GDI and C3 exoenzyme also inhibited EGF-induced migration of IEC- 6 cells. These results demonstrate that $\mathrm{Rho}$ is required for endogenous and EGF-induced migration of small intestinal crypt cells, and that Rho proteins are essential elements of a mechanism by which growth factors induce cell migration to restitute mucosal integrity. (J. Clin. Invest. 1997. 100:216-225.) Key words: cell movement • intestinal mucosa • GTP phosphohydrolase $\bullet$ actin $\bullet$ colitis
\end{abstract}

\section{Introduction}

In the small intestine, cell migration is a fundamental process for the organization and maintenance of tissue integrity (1). When damaged, the gastrointestinal mucosa has the ability to repair itself very rapidly-almost entirely in $24 \mathrm{~h}$ (2). The early phase of repair is termed mucosal restitution and involves the sloughing of damaged epithelial cells and migration of remaining viable cells to reestablish epithelial continuity (3). Using

J. Okolicany is on leave from the Institute for Heart Research, Slovak Academy of Sciences, Bratislava 84233, Slovak Republic.

Address correspondence to Leonard R. Johnson, Department of Physiology and Biophysics, University of Tennessee, College of Medicine, 894 Union Ave., Memphis TN 38163. Phone: 901-448-4793; FAX: 901-448-7126; E-mail: ljohn@physio1.utmem.edu

Received for publication 4 November 1996 and accepted in revised form 31 March 1997.

J. Clin. Invest.

(C) The American Society for Clinical Investigation, Inc.

0021-9738/97/07/0216/10 \$2.00

Volume 100, Number 1, July 1997, 216-225
IEC-6 cells, a nontransformed putative crypt cell line derived from rat small intestine (4), an in vitro model for gastrointestinal cell migration was developed in our laboratory (5). Some aspects of this model resemble the early phase of epithelial cell restitution in the gastrointestinal tract in vivo, such as independence from DNA synthesis and complete dependence on actin polymerization (5).

The precise control of organization of actin filaments is essential for motility, but exactly how this is achieved and regulated is not clear. Several proteins bind actin and colocalize with stress fibers and focal adhesions in response to stimulation with growth factors and serum, but the regulation of cytoskeletal protein assembly also involves proteins that do not bind actin filaments directly (6). Some of these are small GTPbinding proteins that belong to the Rho subfamily, members of the Ras superfamily of small GTPases. The mammalian Rho subfamily comprises $\sim 10$ distinct proteins: Rho (A, B, and C), Rac (1 and 2), Cdc42 (also known as G25K), RhoE, RhoG, and RhoD, and $\operatorname{TC} 10(7,8)$. Characterization of the mammalian Rho proteins has shown that they regulate a signal transduction pathway linking growth factor receptors to the formation of actin stress fibers and focal adhesions $(6,9,10)$. On the other hand, in Swiss 3T3 cells, Rac1 proteins control the polymerization of actin and the assembly of associated focal complexes to produce lamellipodia and membrane ruffles in response to growth factors and serum stimulation $(10,11)$. In these cells, Cdc42, Rac, and Rho work in concert with each other, creating a complex regulatory network for the regulation of the actin cytoskeleton, and consequently cell shape (9). All small GTPases bind and hydrolyze GTP, and their intrinsic GTPase activity is controlled by guanine nucleotide exchange factors (GEFs) and GTPase-activating proteins known as GAPs. Rho guanine nucleotide dissociation inhibitor (GDI) is an inhibitory GEF, which inhibits the dissociation of guanosine diphosphate (GDP) from Rho, Rac, and Cdc42 (12-14).

In the small intestine, EGF and other growth factors stimulate cell migration, as well as cell proliferation and differentiation (15). In several cell lines, activation of the EGF receptor (EGFR) leads to production of extracellular matrix degrading proteases, synthesis of extracellular matrix constituents and reorganization of the cytoskeleton (16-18). In Swiss 3T3 fibroblasts, EGFR activation leads to membrane ruffling and reorganization of focal adhesion through activation of members of the Rho family $(6,11)$.

The first clues to a biological function for Rho proteins

1. Abbreviations used in this paper: $\mathrm{C} 3$, Clostridium botulinum $\mathrm{C} 3$ ADP-ribosyl transferase; dFBS, dialyzed FBS; F-actin, filamentous actin; GDI, guanine nucleotide dissociation inhibitor; GST, glutathion-S-transferase; toxin A, Clostridium difficile glucosyl transferase A; toxin B, Clostridium difficile glucosyl transferase B; 2DGE, two dimensional gel electrophoresis. 
came from the use of the Clostridium botulinum C3 ADP-ribosyltransferase (C3) that modifies Rho (A, B, and C) on Asn41, located in one of its putative effector domains $(19,20)$. ADPribosylation inhibits the function of Rho, without interfering with its GTPase cycle $(21,22)$. As a consequence, when C3 is introduced in a variety of cell types, it causes the loss of actin stress fibers and the rounding up of cells $(6,23)$.

Other toxins, produced by Clostridium difficile, recently have been found to inhibit Rho function. In contrast to C3 toxin, Clostridium difficile glucosyl transferase A and B (toxins $\mathrm{A}$ and $\mathrm{B}$ ) have a broader in vitro specificity modifying Rho (A, $\mathrm{B}$, and $\mathrm{C}$ ), Rac, and $\mathrm{Cdc} 42$ proteins, by glucosylating these proteins at Thr37 (Rho) or Thr35 (Rac and Cdc42), in their effector domains $(24,25)$. Toxins A and B enter intestinal cells and profoundly alter the cytoskeleton, leading to cell rounding (26). Interestingly, toxin-producer strains of $C$. difficile are responsible for virtually all cases of pseudomembranous colitis and for up to $20 \%$ of cases of antibiotic-associated diarrhea without colitis $(27,28)$, suggesting the possible involvement of Rho GTPases in this disease.

In this study, we have investigated the role of the Rho subfamily GTPases in the regulation of migration of two intestinal epithelial cell lines in an in vitro model. First, we showed that incubation of the cells with $C$. difficile toxin A or toxin B inhibits directional migration in a dose-dependent fashion. Second, microinjection of Rho-GDI into IEC- 6 cells inhibited spontaneous migration. Third, the application of $\mathrm{C} 3$ toxin in the culture medium or its microinjection into migrating cells inhibited cell migration in a dose-dependent manner and disrupted the organization of actin stress fibers. We also provided evidence that C3 treatment of IEC-6 cells causes a highly selective ADP-ribosylation of RhoA proteins, suggesting its key role in cell migration. Similar inhibition of the migration of Caco-2 human colonic epithelial cells was found. Fourth, microinjection of recombinant dominant negative RhoT19N or in vitro ADP-ribosylated wild-type RhoA potently inhibited migration, confirming the specificity of $\mathrm{C} 3$ effects in IEC-6 cells. Because C3 toxin and GDI microinjection inhibited not only spontaneous, but also EGF-induced migration of IEC-6 cells, we propose that Rho proteins play an essential role in the early phase of mucosal wound healing through the regulation of growth factor-induced cell migration. Because toxins A and B cause antibiotic-associated diarrhea and pseudomembranous colitis, and our results on Caco- 2 cells reinforce the findings obtained for IEC- 6 cells, it appears that the inactivation of Rho proteins might be an important event in the pathogenic process.

\section{Methods}

Materials. Plastic culture ware was purchased from Corning Glass Works (Corning, NY), and media and other cell culture reagents were obtained from Life Technologies, Inc. (Gaithersburg, MD). Dialyzed fetal bovine serum (dFBS) was from Sigma Chemical Co. (St. Louis, MO), as were all other chemicals, unless specified otherwise. All chemicals for electrophoresis were from Bio-Rad Laboratories (Richmond, CA) or Millipore Corp. (Bedford, MA). EGF and Matrigel were obtained from Collaborative Research Inc. (Lexington/ Waltham, MA). C. botulinum C3 ADP-ribosyl transferase (C3) was obtained from List Biological Laboratories Inc. (Campbell, CA). Rhodamine-phalloidin and fluorescein-phalloidin were obtained from Molecular Probes, Inc. (Eugene, OR), and $\left[{ }^{32} \mathrm{P}\right]$ NAD from Amersham Corp. (Arlington Heights, IL). Purified C. difficile toxins A and
B and the polyclonal antibody anti-C3 toxin were gifts from Dr. Klaus Aktories and Dr. Ingo Just (Institut für Pharmakologie und Toxikologie der Albert-Ludwigs-Universität Freiburg, Freiburg, Germany).

Cell culture. The IEC-6 cell line (CRL 1592; American Type Culture Collection (ATCC), Rockville, MD) between passages 15-20 was used in most experiments. The IEC- 6 stock was maintained in $\mathrm{T}-150$ flasks in a $37^{\circ} \mathrm{C}$ incubator in a humidified atmosphere of $90 \%$ air and $10 \% \mathrm{CO}_{2}$. The culture medium was composed of DME supplemented with $5 \%$ dFBS plus $10 \mu \mathrm{g}$ insulin and $50 \mu \mathrm{g}$ gentamicin sulfate per milliliter (DME-dFBS). The Caco-2 cell line (HTB37; ATCC) between passages 18-23 was also used for some experiments. Cells were maintained similarly to IEC-6 except in an atmosphere of $95 \%$ air and $5 \% \mathrm{CO}_{2}$ in Eagle's MEM with $10 \% \mathrm{dFBS}$ and $50 \mu \mathrm{g}$ gentamicin sulfate per milliliter. Both stocks were passaged weekly and fed three times a week.

Cell migration assay. The cell migration assay was carried out as described previously (5). Briefly, cells were plated in Matrigel-coated $35 \mathrm{~mm}$ dishes at $6.25 \times 10^{4} \mathrm{cells} / \mathrm{cm}^{2}$ in DME-dFBS (IEC-6) or $3.3 \times$ $10^{5} / \mathrm{cm}^{2}$ in MEM-dFBS (Caco-2). To initiate migration (day 4), the cell layer was scraped with a razor blade. The scratch began at the diameter of the dish and extended over an area $30 \mathrm{~mm}$ wide. After wounding, the medium was changed and the dishes were returned to the incubator. After the desired period of time (3-24 h), the area of migration was photographed with a video camera system using the NIH Image software (version 1.58). Cells were counted and data were expressed as the number of migrating cells per millimeter of wounded (scratched area). For the experiments with $\mathrm{C} 3$ toxin, dFBS was removed from the medium and $\mathrm{C} 3$ was added in different concentrations $15 \mathrm{~h}$ before the assay. For the experiments with toxins $\mathrm{A}$ and $\mathrm{B}$, the toxins were added immediately after wounding, in the presence of dFBS.

Microinjections. Confluent cultures were wounded to induce movement, and individual cells along the wound edge and up to three to four rows deep were microinjected with different concentrations of C3 toxin, recombinant proteins Rho GDI gluthathione-S-transferase fusion protein (GST, $0.3 \mathrm{mg} / \mathrm{ml})$, wild-type RhoA $(0.7 \mathrm{mg} / \mathrm{ml})$, RhoT19N $(0.4 \mathrm{mg} / \mathrm{ml})$, or in vitro ADP-ribosylated wild-type RhoA $(0.4 \mathrm{mg} / \mathrm{ml})$, using an Eppendorf Model 5242 micromanipulator and 5171 microinjector attached to an Olympus IMT2 inverted microscope equipped with phase contrast and epifluorescence capabilities. All microinjected solutions contained $0.2-2.0 \mathrm{mg} / \mathrm{ml}$ Texas red-labeled dextrane $(150 \mathrm{kD})$. Approximately 150-200 cells were injected per dish within a $20 \mathrm{~min}$ period. After $3-24 \mathrm{~h}$ incubation at $37^{\circ} \mathrm{C}$, the number of migrating cells per millimeter was determined and cells were stained for filamentous (F)-actin. For each dish, noninjected cells were used as controls. In separate assays, cells were injected with the vehicle (deionized water, $0.3 \mathrm{mg} / \mathrm{ml} \mathrm{GST}$ or the appropriate buffer) under similar conditions. For the experiments with EGF, dFBS was removed from the medium $15 \mathrm{~h}$ before the assay and EGF $(30 \mathrm{ng} / \mathrm{ml})$ was added to the medium immediately after microinjection.

Actin staining. Cells were fixed and permeabilized with $3.7 \%$ paraformaldehyde $/ 0.2 \%$ Triton X-100 at room temperature for $5 \mathrm{~min}$ and postfixed with $95 \%$ ethanol for $5 \mathrm{~min}$ at $-20^{\circ} \mathrm{C}$. F-actin was detected by rhodamine-phalloidin or fluorescein-phalloidin staining. Samples were imaged with a Laser Sharp Bio-Rad MRC-1024 Laser Scanning Confocal Imaging System (Bio-Rad Laboratories).

Cell fractionation and $\left.{ }^{32} P\right] A D P$ ribosylation. ADP ribosylation assays were done by the method described by Jalink et al. (29). Cells were homogenized in the presence of protease inhibitors and fractionated into cytosol and crude membrane fractions. Protein was determined by the method of Bradford (30). Membrane or cytosolic fractions (30 $\mu \mathrm{g}$ protein) were incubated in the presence of $10 \mu \mathrm{Ci} / \mathrm{ml}$ $\left[{ }^{32} \mathrm{P}\right]$ NAD (Amersham Corp.), and $5 \mu \mathrm{g} / \mathrm{ml} \mathrm{C} 3$ toxin. ADP-ribosylated proteins were separated by SDS-PAGE and visualized by autoradiography using Kodak X-Omat film (Eastman Kodak Co., Rochester, NY). Recombinant wild-type RhoA was ADP-ribosylated in vitro with $\mathrm{C} 3$ toxin according to the method described by Paterson et al. (23). In this reaction, recombinant RhoA protein $(0.5 \mathrm{mg} / \mathrm{ml})$ was 
incubated with $0.3 \mu \mathrm{g} / \mathrm{ml} \mathrm{C} 3$ toxin for $60 \mathrm{~min}$ in buffer (10 mM Tris, $50 \mathrm{mM} \mathrm{NaCl}, \mathrm{pH}$ 7.4, $0.1 \mathrm{mM}$ GTP, $0.5 \mathrm{mM}$ NAD). C3 exoenzyme was then removed by immunoprecipitation with a polyclonal antibody against the toxin (31), followed by adsorption of the antibody with Protein A/G-Sepharose 4B (Santa Cruz Biotechnology, Santa Cruz, CA). Immunoprecipitation of the toxin greatly reduced the amount of free enzyme, as monitored by the addition of $\left[{ }^{32} \mathrm{P}\right] \mathrm{NAD}$ and wild-type RhoA to the recombinant proteins (after immunoprecipitation of C3) for $30 \mathrm{~min}$, followed by 15\% SDS-PAGE and PhosphorImager (Molecular Dynamics, Sunnyvale, CA) analysis of the labeled proteins. Two dimensional gel electrophoresis (2DGE) was done according to the method originally described by O'Farrell (32), in the 3-10 $\mathrm{pH}$ range, using the Investigator 2-D electrophoresis system from Millipore Corp. For the second dimension $12.5 \%$ gels were used.

Preparation of recombinant proteins. cDNAs of Rho-GDI, wild type, and the mutant form of RhoA were subcloned into the BamHI and EcoRI sites of pGEX-KG vector and expressed in Escherichia coli as GST fusion proteins (33). Expression and purification of recombinant proteins from the pGEX-transformed E. coli were carried out as described previously (34). The concentration of functional protein was estimated by Coomassie Blue-stained SDS-PAGE, using BSA as a standard, and by $\left[{ }^{35} \mathrm{~S}\right] \mathrm{GTP}$ binding (35). The purity of the prepa-
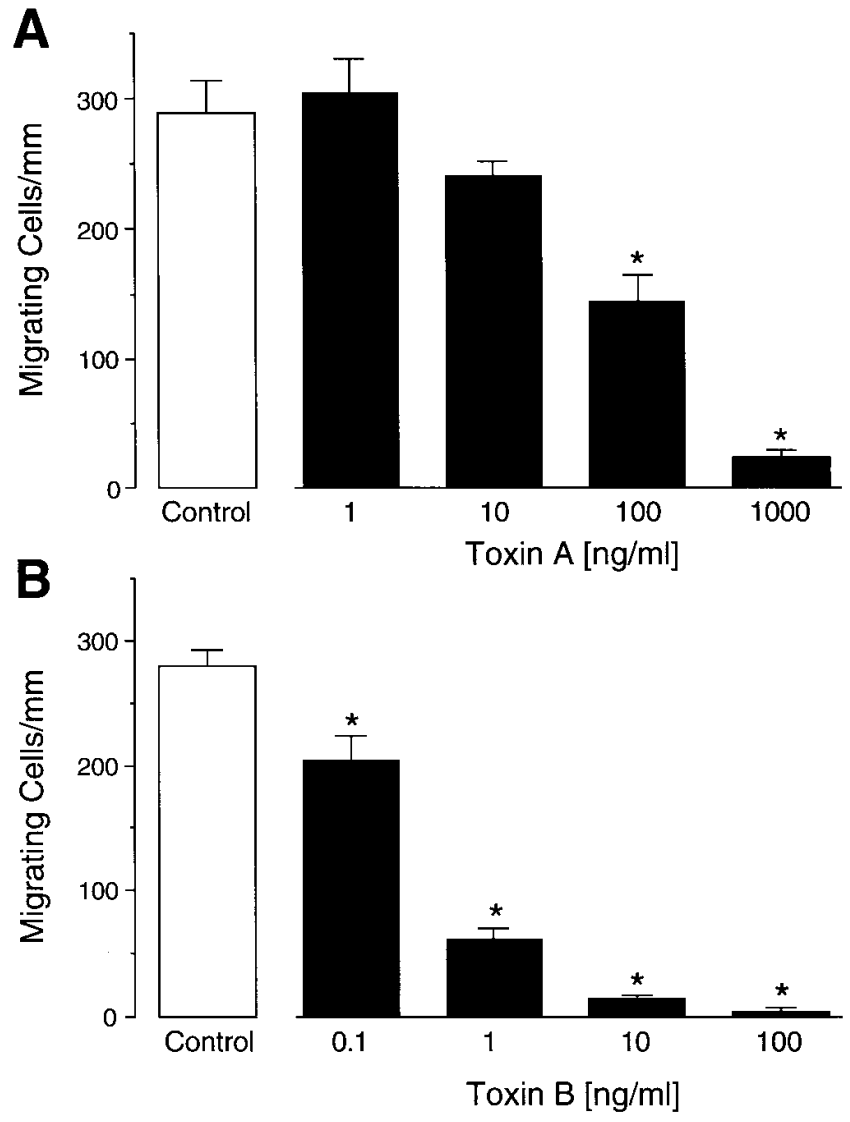

Figure 1. C. difficile toxins A and B inhibit cell migration. Monolayers were wounded to induce migration, and toxins $\mathrm{A}(A)$ and $\mathrm{B}(B)$ were added to the medium. Cell migration was determined $3 \mathrm{~h}$ later. Both toxins inhibited cell migration in a dose-dependent fashion, toxin $\mathrm{B}$ was $\sim 100$ times more potent than toxin A. Data are expressed as migrating cells per millimeter of scratched area (mean \pm SEM, $n=6$ ). *Significant differences when compared to the nontreated group using ANOVA $(P<0.05)$. rations was $\sim 90 \%$. Recombinant proteins were taken up in $20 \mathrm{mM}$ Tris, $50 \mathrm{mM} \mathrm{NaCl}, 2 \mathrm{mM} \mathrm{MgCl} 2$ (pH 7.6) buffer for microinjection.

Statistical analysis. ANOVA followed by Tukey's procedure was used, and results were considered significantly different at $P<0.05$.

\section{Results}

C. difficile toxins $A$ and $B$ inhibit migration of IEC-6 cells. To establish the involvement of Rho family proteins in migration, IEC- 6 cells were allowed to migrate for $3 \mathrm{~h}$ in the presence of toxins $\mathrm{A}$ and $\mathrm{B}$ in the medium. Both toxins inhibited migration in a dose-dependent fashion (Fig. 1, $A$ and $B$ ). The lowest dose of toxin A to inhibit migration was $100 \mathrm{ng} / \mathrm{ml}$ (50\% inhibition), whereas, $1,000 \mathrm{ng} / \mathrm{ml}$, the highest dose used, inhibited migration almost completely by $92 \%$, causing cell rounding and sometimes detachment. Based on their dose-response relationship, toxin $\mathrm{B}$ was $\sim 100$ times more potent inhibiting migration. The low dose of $0.1 \mathrm{ng} / \mathrm{ml}$, was already highly effective impairing migration by $27 \%$, whereas the high dose of $100 \mathrm{ng} /$ $\mathrm{ml}$ abolished migration completely.

Rho-GDI inhibits cell migration. To confirm the results obtained with the toxins A and B, recombinant Rho-GDI-GST protein was microinjected at a concentration of $0.3 \mathrm{mg} / \mathrm{ml}$, whereas GST protein served as control. Cell migration was determined $4 \mathrm{~h}$ after injection (Fig. 2). Rho-GDI blocked migration up to $70 \%$ when compared with noninjected and control GST-injected cells, whereas GST protein alone did not significantly alter cell migration compared to noninjected control cells.

C. botulinum $C 3$ toxin blocks cell migration. To narrow the focus of our investigation within the Rho subfamily, next we examined the effect of the Rho-selective C3 ADP-ribosyltransferase on cell migration by adding the toxin to the medium $15 \mathrm{~h}$ before the assay. This lengthy preincubation was necessary because the toxin is not readily taken up by the cells. Treatment with C3 inhibited IEC-6 cell migration in a dosedependent manner (Fig. $3 A$ ). The lowest effective dose to inhibit migration was as little as $1.0 \mu \mathrm{g} / \mathrm{ml}$ causing $30 \%$ inhibition, compared with nontreated cells. Similarly, with IEC-6

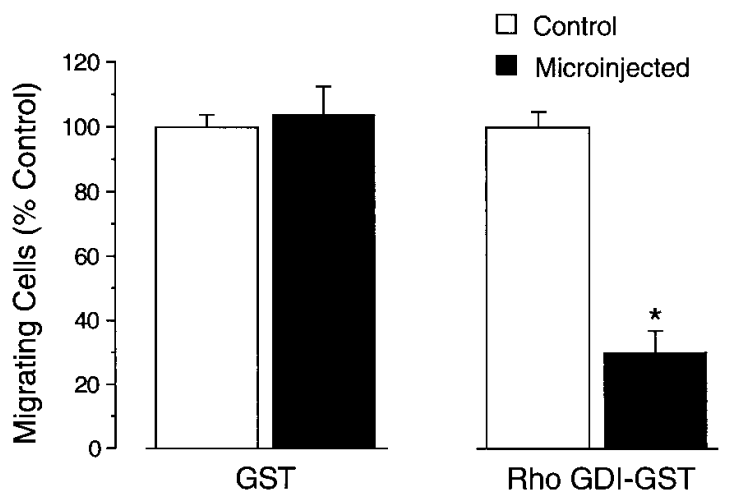

Figure 2. Microinjection of Rho GDI inhibits IEC-6 cell migration. Cell migration was compared between cells microinjected with 0.3 $\mathrm{mg} / \mathrm{ml}$ of either Rho GDI-GST, or GST alone and noninjected controls. GST alone did not impair cell migration whereas, in cells microinjected with Rho GDI-GST, migration was reduced by $70 \%$. Approximately 200 cells were injected per assay. Noninjected control cell migration was considered $100 \%$, and data are expressed as percent of control (mean \pm SEM, $n=4)$. *A significant difference when compared to the noninjected group using ANOVA $(P<0.05)$. 

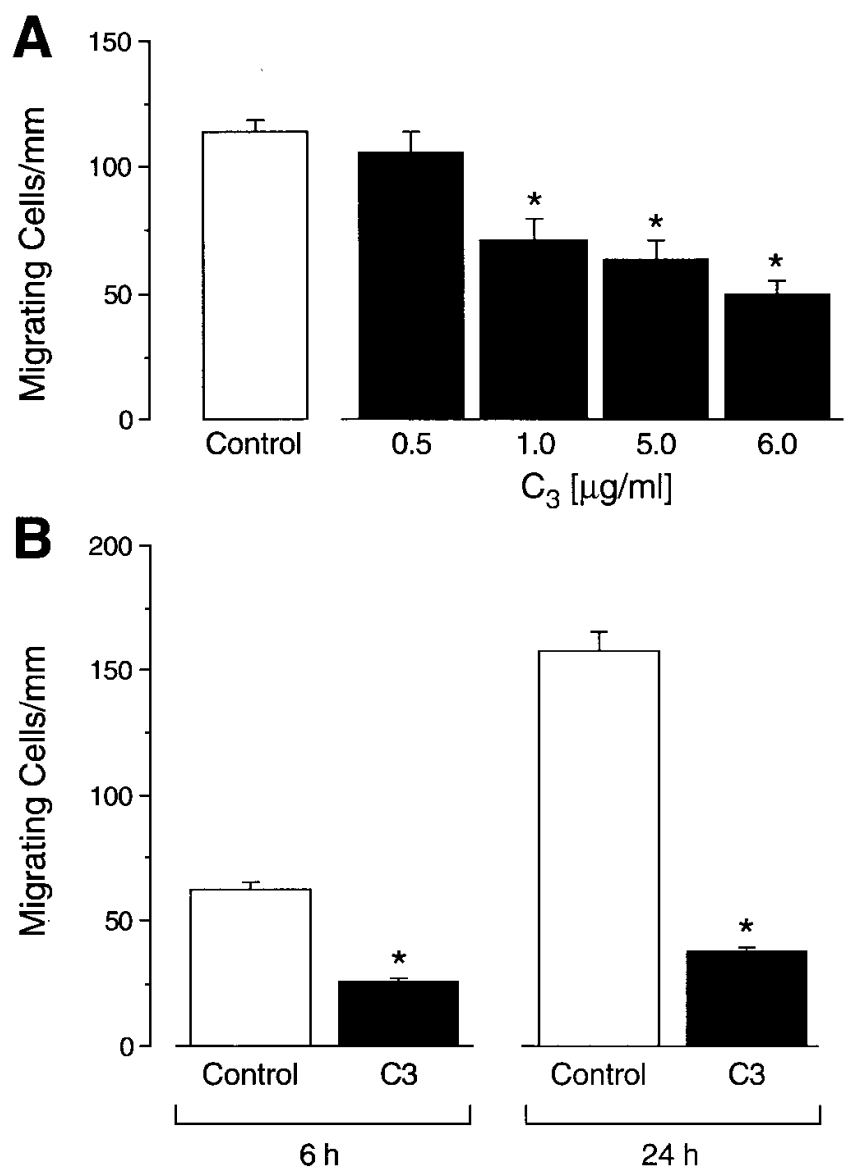

Figure 3. Application of $\mathrm{C} 3$ toxin to the culture medium inhibits the migration of IEC-6 and Caco- 2 cells. On day 3 C 3 toxin $(0.5-10.0 \mu \mathrm{g} / \mathrm{ml})$ was added in serum free medium. After a 15 -h incubation, monolayers were wounded and 5\% dFBS was added to the medium, and cell migration was monitored $3 \mathrm{~h}$ later for IEC-6 cells $(A), 6$ and $24 \mathrm{~h}$ later for Caco-2 cells $(B)$. Caco-2 cells were incubated with a single dose of $10 \mu \mathrm{g} / \mathrm{ml} \mathrm{C} 3$ toxin. Data are expressed as migrating cells per millimeter (mean \pm SEM, $n=6$ ). *Significant differences from control group using ANOVA $(P<0.05)$.

cells, the migration of Caco-2 human colon carcinoma cells was also inhibited in the presence of $10 \mu \mathrm{g} / \mathrm{ml} \mathrm{C} 3$ toxin (Fig. 3 $B)$. The inhibition increased from $60 \%$ at $6 \mathrm{~h}$ after wounding to $76 \%$ after $24 \mathrm{~h}$, while cell viability was not affected.

Distribution of F-actin in IEC-6 cells was monitored with rhodamine-phalloidin staining after incubation with $6 \mu \mathrm{g} / \mathrm{ml}$ C3. Control IEC-6 cells showed long stress fibers traversing the cytoplasm, a thick network of cortical actin fibers just beneath the plasma membrane, and fine actin fibers extending into numerous filopodia and microspikes (Fig. $4 A$ ). Numerous lamellipodia were observed in migrating cells. After treatment with $\mathrm{C} 3$ toxin, cells localized in the proximity of the wound showed fewer actin stress fibers, and F-actin appeared disorganized throughout the cytoplasm. Cells along the migrating edge appeared to spread out, and showed numerous membrane ruffles towards the leading edge (Fig. $4 \mathrm{~B}$ ). Stimulation with EGF for $3 \mathrm{~h}$ increased migration, as also evidenced by the increased spaces between migrating cells and the abundant presence of stress fibers (Fig. $4 C$ ). The increase in stress fibers in cells could be observed as early as 5 min after addition of EGF to the medium (data not shown). The phenotype characterized by decrease in stress fibers, observed previously in C3treated cells, was even more pronounced after combined treatment with C3 and EGF (Fig. 4D).

C3 toxin was also microinjected into the cytoplasm of IEC-6 cells located close to the wound edge. Microinjection of $\mathrm{C} 3$ toxin, just like its medium application, inhibited migration in a dose-dependent fashion (Fig. 5). Cells injected with solvent showed no significant reduction in their migration compared to noninjected controls. After the microinjection of C3 toxin, cultures were stained with fluorescein-phalloidin. Noninjected control cells or solvent-injected cells marked by rhodaminedextrane revealed a pattern of scattered stress fibers with interconnected bundles of actin filaments throughout the cytoplasm (Fig. $6 \mathrm{~A}$ ). The injection of $0.1 \mathrm{mg} / \mathrm{ml} \mathrm{C3}$ toxin solution reproduced the effects on the organization of F-actin observed previously after incubation with $6 \mu \mathrm{g} / \mathrm{ml}$ toxin for $15 \mathrm{~h}$ (Fig. $6 \mathrm{~B})$. A visual correlation between the inhibition of migration and disappearance of stress fibers was apparent after microinjection of high doses of C3 toxin. The injection of doses higher than $0.1 \mathrm{mg} / \mathrm{ml}$ not only inhibited the formation of new fibers, but also led to the complete disappearance of preexisting stress fibers. After microinjecting C3 at a concentration of $1 \mathrm{mg} / \mathrm{ml}$, cells rounded up, and only the cortical F-actin remained detectable (data not shown). Nonetheless, cells remained attached to the matrix.

C3 toxin selectively ADP-ribosylates RhoA in IEC-6 cells. To establish the specificity of C3 toxin treatment for Rho proteins in IEC-6 cells, ADP-ribosylation reactions were carried out in vitro using $\left[{ }^{32} \mathrm{P}\right] \mathrm{NAD}$. Autoradiography showed a single band with an apparent molecular mass of $21 \mathrm{kD}$ both in the cytosolic and crude membrane fractions (Fig. $7 A$ ). The amount of $\mathrm{C} 3$ substrate in the cytosolic fraction was much higher than in the membrane fraction (Fig. $7 A$ ). To identify the $21-\mathrm{kD}$ proteins present in the labeled band, 2DGE was applied. Autoradiography of $2 \mathrm{DGE}$ revealed only a single spot, with pI 5.9 , which is identical to that of RhoA (Fig. $7 \mathrm{~B}$ ). The identity of the C3-labeled band was also confirmed by Western blotting with the anti-RhoA-specific monoclonal antibody (data not shown). Confirming the results of the 2DGE-autoradiography, reverse transcription-PCR (RT-PCR) and Southern analysis of RhoA, B, and C in IEC- 6 cells revealed only the expression of RhoA, whereas RhoB or C, if expressed, were below the detectability of these assays (data not shown).

Dominant negative forms of RhoA inhibit cell migration. To confirm that the effects of $\mathrm{C} 3$ on cell migration were due to the selective modification of Rho proteins in situ, wild-type recombinant protein RhoA was ADP-ribosylated in vitro. Subsequently, C3 was removed by immunoprecipitation, and the modified protein was microinjected into migrating cells. The ADP-ribosylated protein is unable to activate its targets but, because of its intact GTPase cycle, it competes with endogenous Rho for exchange factors thus acting as a dominant negative mutant (23). Recombinant true dominant negative RhoT19N mutant form of the GTPase was also prepared and microinjected, along with wild-type RhoA protein. Both forms of dominant negative RhoA inhibited cell migration: RhoT19N inhibited by $\sim 50 \%$, whereas ADP-ribosylated RhoA inhibited by $\sim 70 \%$ (Fig. 8). Microinjection of buffer after addition and immunoprecipitation of $\mathrm{C} 3$ did not affect migration, confirming the lack of functionally relevant amounts of residual 

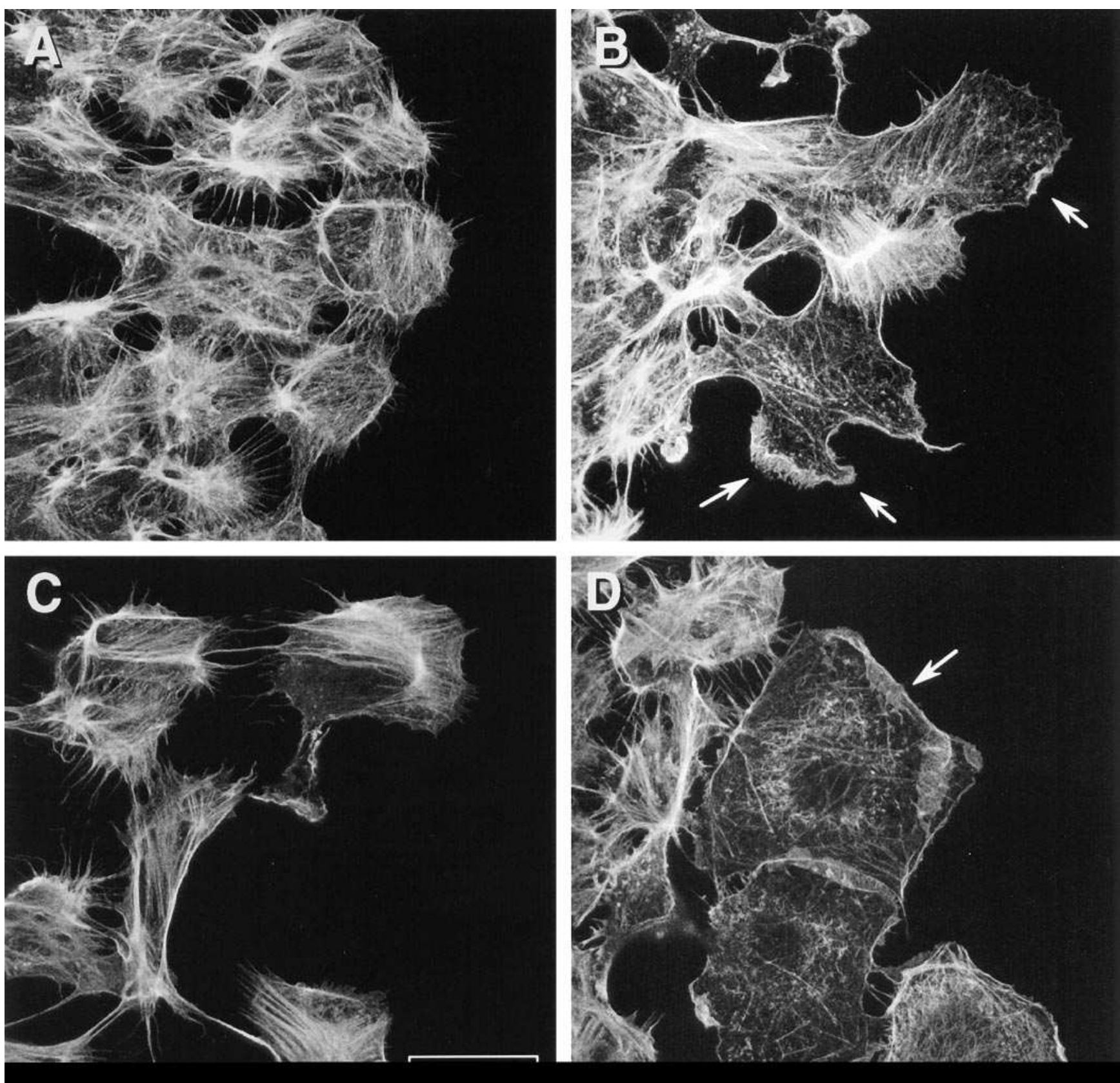

Figure 4. C3 toxin inhibits stress fiber formation in migrating IEC-6 cells. F-actin staining with rhodamine phalloidin in migrating IEC-6 cells, cultured for $15 \mathrm{~h}$ in control medium $(A)$, medium containing $6 \mu \mathrm{g} / \mathrm{ml} \mathrm{C} 3$ toxin $(B), 30 \mathrm{ng} / \mathrm{ml} \mathrm{EGF}(C)$, or $6 \mu \mathrm{g} / \mathrm{ml} \mathrm{C} 3$ toxin $+30 \mathrm{ng} / \mathrm{ml} \mathrm{EGF}(D)$. Migrating C3 toxin-treated cells showed fewer stress fibers, yet displayed numerous membrane ruffles over the leading edge (arrows, $B$ ). EGF treatment increased stress fibers in migrating cells leading to an increase in the size of gaps between cells $(C)$. Cells treated with $\mathrm{C} 3$ toxin plus EGF were spread, showing disorganization of the actin cytoskeleton and numerous membrane ruffles (arrow, $D$ ). Confocal images; calibration bar, $25 \mu \mathrm{m}$.

C3 in the preparation. On the other hand, microinjection of 0.7 $\mathrm{mg} / \mathrm{ml}$ wild-type RhoA did not affect cell migration (Fig. 8).

To study the effects of these recombinant proteins on F-actin distribution, subconfluent IEC-6 cells were microinjected with wild-type RhoA $(0.7 \mathrm{mg} / \mathrm{ml})$ or dominant negative RhoT19N (0.4 mg/ml), whereas buffer was used as control. F-actin was stained with rhodamine-phalloidin after $30 \mathrm{~min}$ of incubation. Buffer-injected cells showed numerous actin stress fibers traversing the cytoplasm, and thick bundles of cortical F-actin. Lamellipodia were frequently present (Fig. 9 A). Mi- croinjection of wild-type RhoA slightly increased the number of stress fibers, compared to buffer-injected cells (Fig. $9 \mathrm{~B}$ ). In contrast, cells microinjected with RhoT19N were devoid of stress fibers, and showed an accumulation of cortical F-actin. However, lamellipodia were preserved (Fig. $9 C$ ). These phenomena and the distribution of F-actin was similar to that observed in cells microinjected with $\mathrm{C} 3$ toxin (Fig. $6 B$ ).

Microinjection of Rho GDI and C3 toxin also inhibit EGFinduced cell migration. Epidermal growth factor stimulates migration of intestinal cells in vivo and in vitro, playing a phys- 


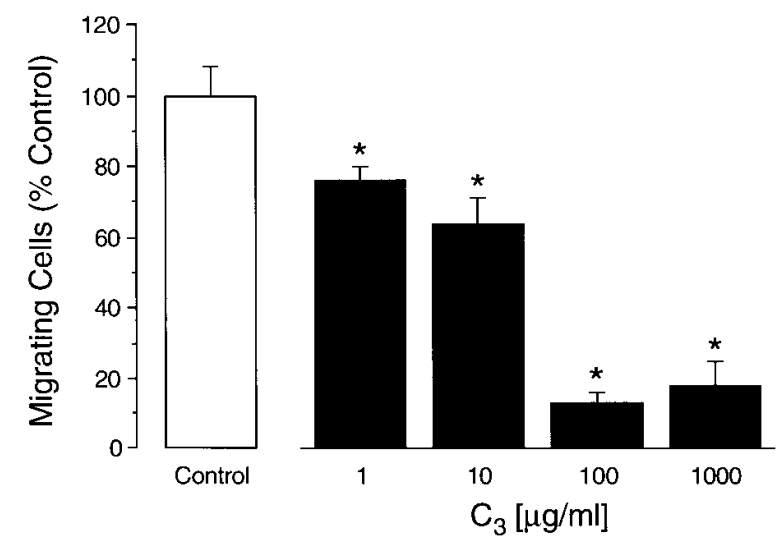

Figure 5. Microinjection of $\mathrm{C} 3$ toxin inhibits IEC-6 cell migration. Cells located in the migrating edge were microinjected with different doses of C3 immediately after wounding, and migration was measured $4 \mathrm{~h}$ later. Approximately 200 cells were injected per group. The number of migrating cells per millimeter in the control was considered $100 \%$, and data are expressed as percent of control (mean \pm SEM, $n=4)$. *Significant differences when compared to the control-injected group using ANOVA $(P<0.05)$.

iologically relevant role during the early phase of wound healing in the small intestine (15). To determine if Rho proteins are also involved in EGF-stimulated migration, $0.3 \mathrm{mg} / \mathrm{ml}$ of Rho GDI-GST or C3 toxin was microinjected into serumstarved cells along the edge of the wound and $30 \mathrm{ng} / \mathrm{ml} \mathrm{EGF}$ was added to the medium. Migration was measured after $3 \mathrm{~h}$. EGF treatment increased migration by $~ 50 \%$ over control. In contrast, microinjection of C3 or Rho-GDI abolished completely the stimulatory effect of EGF (Fig. 10).

\section{Discussion}

In this study, we demonstrate for the first time that Rho proteins are important for spontaneous and EGF-induced migration of intestinal epithelial cells, suggesting that inhibition of Rho function may delay the early phase of the mucosal healing process. This conclusion bears pathological significance and is supported by several lines of evidence.

Toxins A and B are the virulence factors secreted by $C$. difficile, which enter intestinal cells through surface receptors and cause the disruption of the cytoskeleton, rounding up and retraction of the cell body (36). Toxin A also produces fluid secretion, mucosal damage, and intestinal inflammation when injected into the rodent intestine (37). Toxin $\mathrm{B}$ is $\sim 1,000$ times more potent than toxin $\mathrm{A}$ as a cytotoxin in tissue culture and it was recently shown to be also enterotoxic in the human colonic mucosa (38). We found that exposure of IEC-6 cells to toxins $\mathrm{A}$ or $\mathrm{B}$ inhibited cell migration in a dose-dependent manner, with toxin $\mathrm{B}$ being $\sim 100$-fold more potent with an $\mathrm{EC}_{50}$ in the $1 \mathrm{ng} / \mathrm{ml}$ range (Fig. $1 B$ ). In vitro, both toxins specifically glucosylate Rho (A, B, and C), Rac, and Cdc42 proteins, and block their function. Just et al. (39) showed that overexpression of RhoA protein in cells attenuated cell rounding caused by exposure of cells to toxin B. Corroborating these results, Dillon et al. (40) found that the stability of B toxinmodified RhoA in NIH3T3 fibroblasts is reduced and it disappears within hours from the membrane, without detectable effects on the stability of Cdc42 and Rac1.

Rho-GDI is an inhibitory exchange factor regulator for members of the Rho subfamily (12), which binds preferentially to the GDP-bound form of the GTPase (41). Microinjection of Rho-GDI into IEC-6 cells almost completely abolished migration (Fig. 2), confirming the importance of the Rho family GTPases in this process. However, Rho GDI has a broad specificity
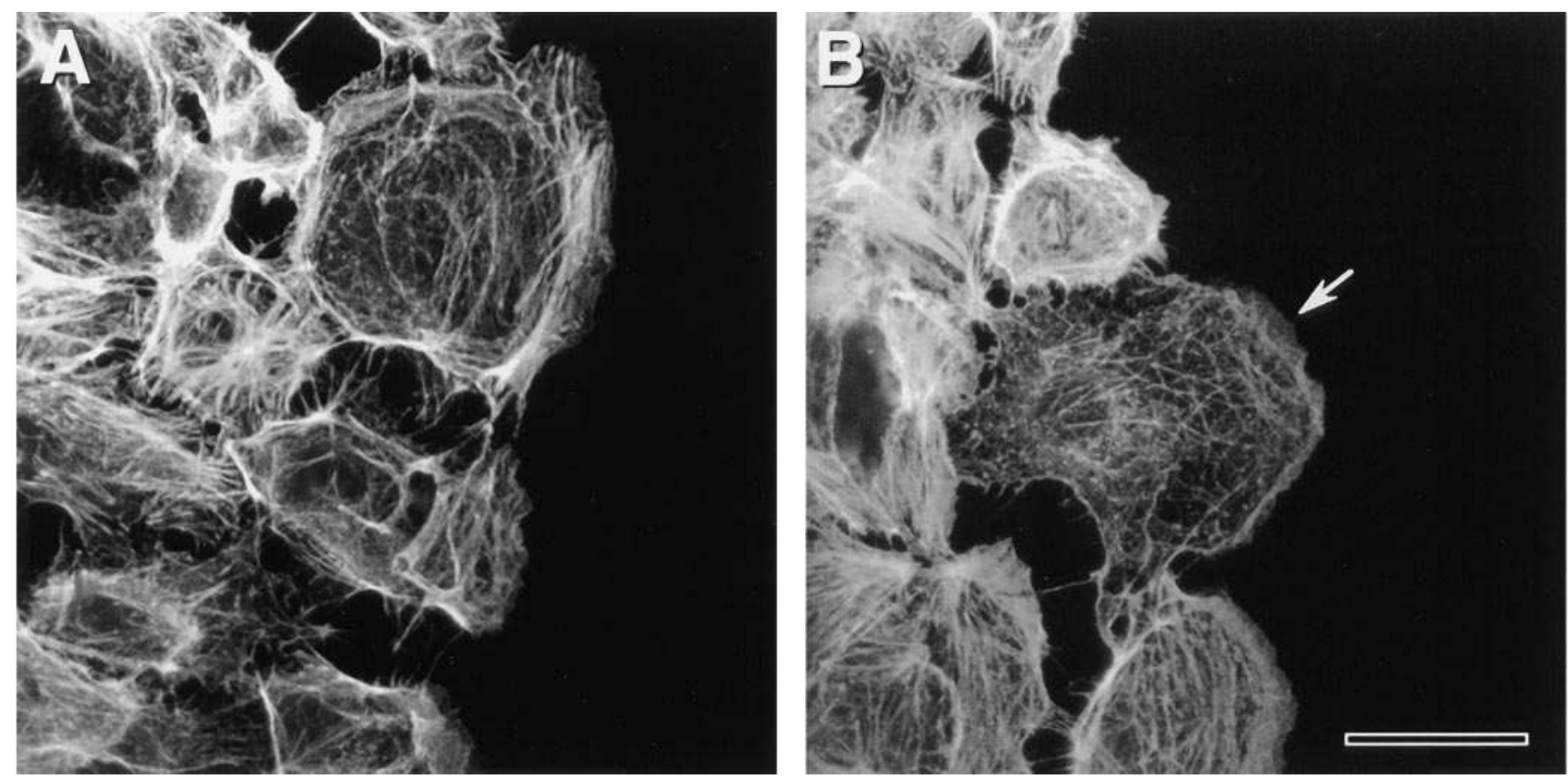

Figure 6. Microinjection of $\mathrm{C} 3$ toxin inhibits stress fibers formation in migrating IEC-6 cells. Cells located in the migrating edge were microinjected with solvent $(A)$ or $0.1 \mathrm{mg} / \mathrm{ml} \mathrm{C} 3$ toxin $(B)$. F-actin was stained $3 \mathrm{~h}$ later using fluoresceine-phalloidin. The arrow points to a cell showing disorganized F-actin. Approximately 200 cells were injected per group. Confocal images; calibration bar, $25 \mu \mathrm{m}$. 

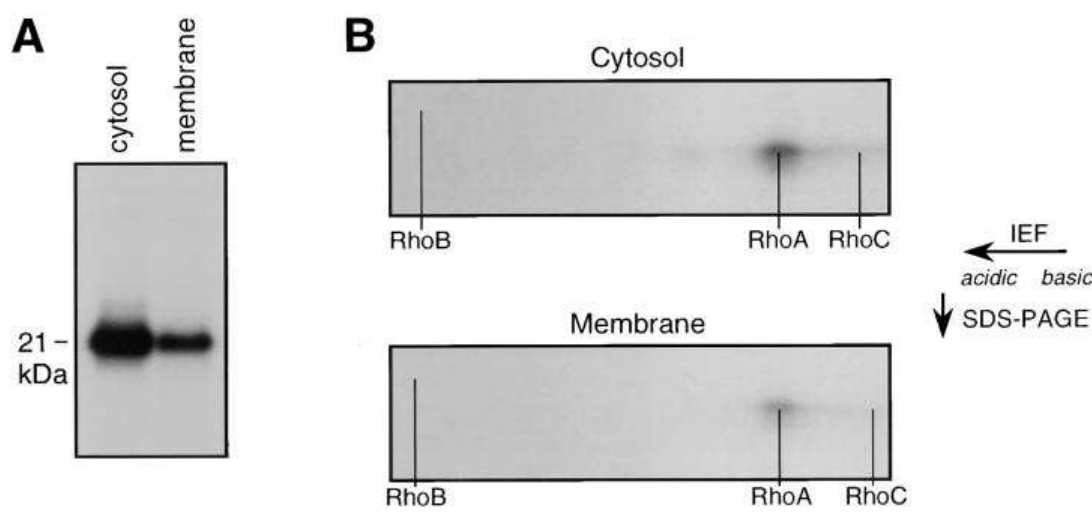

Figure 7. RhoA is the target for $\mathrm{C} 3$ toxin-mediated ADP-ribosylation in IEC-6 cells. Cells were fractionated into cytosolic and crude membrane fractions and cell lysates were ADP-ribosylated by $\mathrm{C} 3$ in vitro, using $\left[{ }^{32} \mathrm{P}\right] \mathrm{NAD}$ as substrate. Autoradiography of the fractions separated by $15 \%$ SDS-PAGE showed that only a single $21 \mathrm{kD}$ band was labeled $(A)$. Cytosolic and crude membrane fractions were ADP-ribosylated by $\mathrm{C} 3$ in vitro, using $\left[{ }^{32} \mathrm{P}\right] \mathrm{NAD}$ as substrate and samples were analyzed by $2 \mathrm{DGE}$ ( $\mathrm{pH}$ range $3.0-10.0$ ) followed by autoradiography $(B)$. Only a single spot with pI 5.9 was labeled, which corresponds to RhoA. The position of RhoB and RhoC are marked by arrows, based on parallel ADP-ribosylation of PC12 pheochromocytoma extracts, which contain all three Rho proteins.
(12), and consequently, it does not permit the identification of which of the Rho GTPases is necessary for normal cell migration.

Among the over 50 members of the family of small $\mathrm{G}$ proteins, only Rho proteins (RhoA, B, and C) are ADP-ribosylated by $\mathrm{C} 3$ toxin. Rac proteins are very poor substrates for this enzyme in vitro (42). After C3 treatment, IEC-6 cell migration was inhibited, accompanied by significant alterations in the distribution of F-actin in migrating cells without any indication of cell detachment. Morphological features accompanying C3 treatment, such as the reduction of actin stress fibers in migratory cells, appear to be linked to the inhibition of migration because migrating control IEC- 6 cells showed many stress fibers, and EGF, which stimulated cell migration, also stimulated stress fiber formation. The effects of C3 on migra-

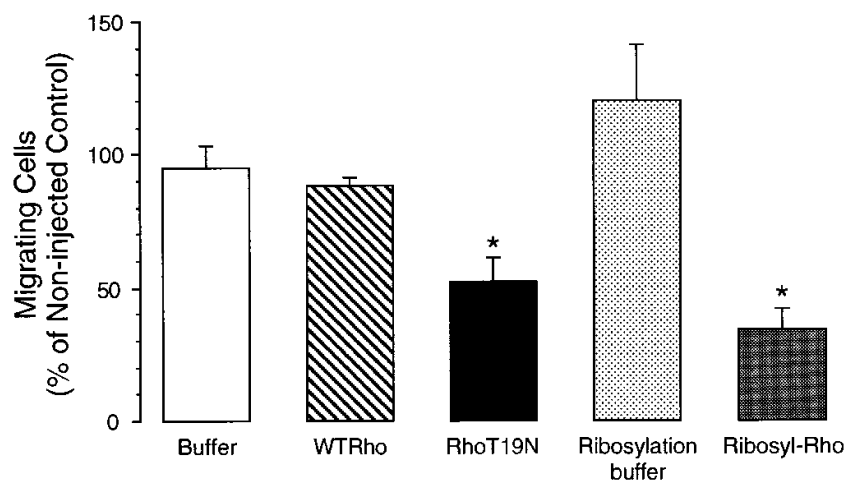

Figure 8. Microinjection of dominant negative forms of RhoA inhibits cell migration. Cells located along the migrating edge were microinjected with different recombinant proteins: wild-type RhoA ( 0.7 $\mathrm{mg} / \mathrm{ml})$, RhoA ADP-ribosylated in vitro $(0.4 \mathrm{mg} / \mathrm{ml})$, or dominant negative RhoT19N $(0.4 \mathrm{mg} / \mathrm{ml})$. C3 toxin was removed by immunoprecipitation with a polyclonal anti-C3 antibody. Control cells were microinjected with buffer before (open bar) and after immunoprecipitation of C3 (dotted bar). Microinjection was done immediately after wounding and migration was measured $5 \mathrm{~h}$ later. Approximately 200 cells were injected per group. The control cell migration rate for each dish (noninjected cells) was considered $100 \%$, and data are expressed as percent of control (mean \pm SEM, $n=4)$. *Significant differences from the control group using ANOVA $(P<0.05)$. tion were not limited to small intestinal crypt cells, since the Caco-2 human colon carcinoma cells were also affected in a similar way by this toxin.

The potency of C3 toxin is greatly limited by its poor uptake into cells, which varies from cell line to cell line. To circumvent the uptake limitation, different doses of C3 were microinjected. C3 toxin not only inhibited migration in a dosedependent manner, but also inhibited the formation of stress fibers. After microinjection of a high concentration of C3, those few cells that crossed the wound line were not labeled with rhodamine-dextrane. Thus, some noninjected cells started from behind the region of injection and migrated through gaps between the stalled C3-injected cells. Furthermore, microinjection of in vitro ADP-ribosylated recombinant RhoA into migrating cells potently impaired migration when compared to buffer-injected cells, indicating that the effects observed after medium application or microinjection with $\mathrm{C} 3$ were consistent and likely to be due to the selective ADP-ribosylation of Rho (Fig. 8). Moreover, microinjection of the dominant negative protein RhoT19N, which is permanently locked into the GDPbound inactive state and competes for exchange factors during activation of Rho (43), also inhibited migration, confirming the importance of the activation of Rho during migration (Fig. 8). On the other hand, the fact that wild-type Rho did not alter cell migration suggests that migration is not limited by the availability of Rho in IEC-6 cells. Our results differ from those obtained by Ridley et al. in MDCK cells (44), showing that the microinjection of activated Rho inhibits spreading and scattering, while inhibition of Rho function leads to the disappearance of stress fibers and peripheral bundles but does not prevent HGF-induced motility. These differences might be attributed, at least in part, to the differences in the cell types and their endogenous migratory properties.

In IEC-6 cells, we also showed that C3 specifically ADPribosylates both cytosolic and membrane-bound RhoA. In 2DGE, only one ribosylated protein was detected, with a pI corresponding to that of RhoA (45; Fig. 7 B). We did not detect RhoB or RhoC as substrates for $\mathrm{C} 3$ with $2 \mathrm{DGE}$ autoradiography. Furthermore, under the conditions applied during the migration assay, we could not detect mRNA for RhoB and RhoC after RT-PCR followed by Southern hybridization (data not shown). However, the possibility of RhoB and RhoC expression only in migratory cells can not be ruled out. Our re- 

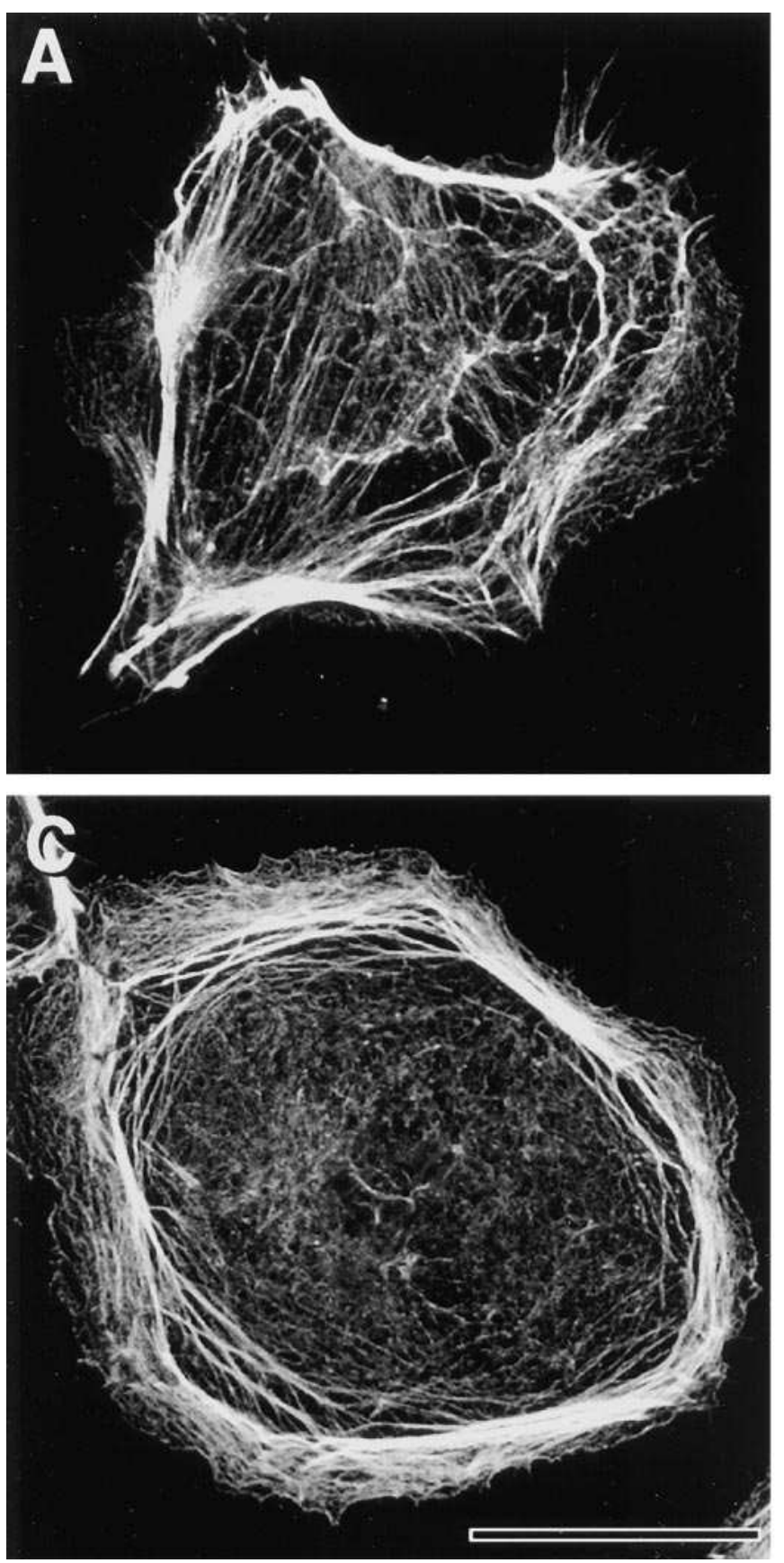

sults showed that the C3 substrate was approximately three times more abundant in the cytosol of IEC-6 cells, corroborating the results of Fritz et al. (46), reporting that in most tissues Rho proteins are 2-3-fold more abundant in the cytosol than in the membrane fraction.

Upon ligand activation, several tyrosine kinase growth factor receptors induce a substantial reorganization of the actin cytoskeleton. This change in actin superstructure is necessary to produce multiple motile responses within the target cells (47). Because EGF has been shown to be a physiologically relevant regulator of motility and regeneration in intestinal epithelial cells, we analyzed the impact of Rho proteins on EGFinduced migration. Microinjection of Rho-GDI and C3 toxin completely blocked EGF-induced motility (Fig. 10), reinforc-

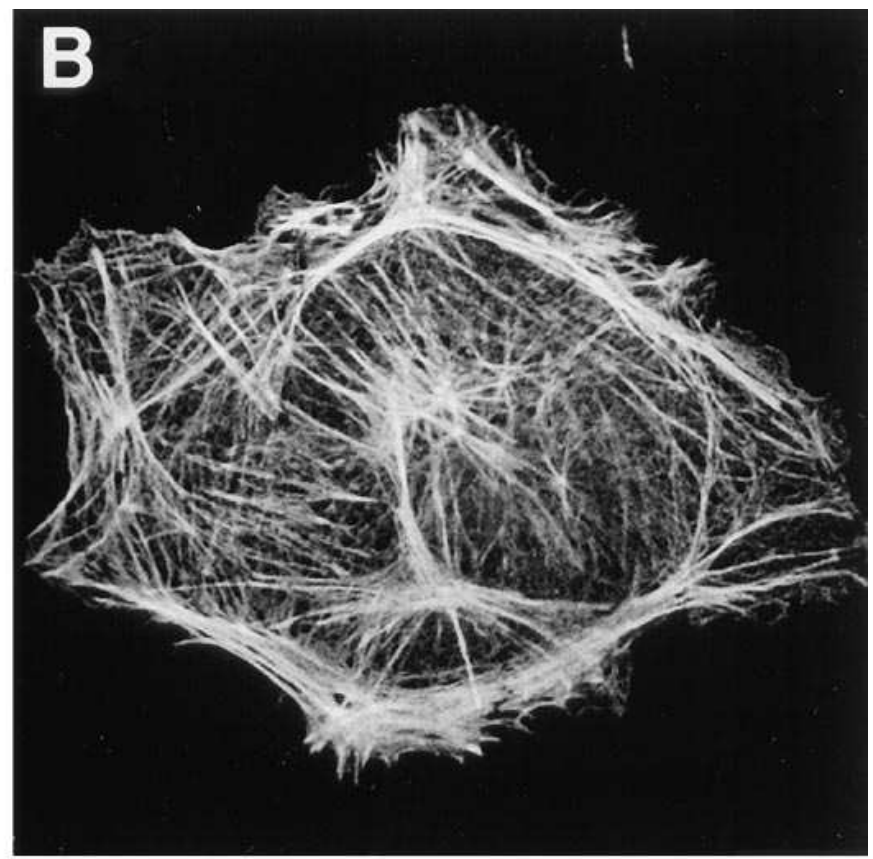

Figure 9. Microinjection of dominant negative RhoT19N induces the disassembly of actin stress fibers. Subconfluent cells were microinjected with buffer $(A)$, wild-type RhoA $(0.7 \mathrm{mg} / \mathrm{ml}, B)$, or RhoT19N $(0.4 \mathrm{mg} / \mathrm{ml}, C)$. After microinjection, cells were incubated for $30 \mathrm{~min}$, fixed, and stained with rhodamine-phalloidin. Wild-type RhoA did not alter F-actin distribution, whereas RhoT19N-injected cells were devoid of actin stress fibers. Confocal images; calibration bar, $20 \mu \mathrm{m}$.

ing the idea that the impairment of Rho proteins might delay the healing process in the small intestine by inhibiting endogenous as well as growth factor-induced migration. Previous reports have shown that Rho function may be directly related to random motility, which is different from the directional migration of IEC-6 cells. For example, C3 toxin inhibits spontaneous and chemoattractant-induced motility of neutrophils (48), as well as spontaneous motility of sperm cells (49). After microinjection of C3 in 308R keratinocytes, hepatocyte growth factor (HGF)-induced nondirectional motility was inhibited for up to 24 hours (50).

Here, we propose that Rho proteins are essential for migration of intestinal epithelial cells. However, we did not rule out the possibility or argue against the hypothesis that Rac or 


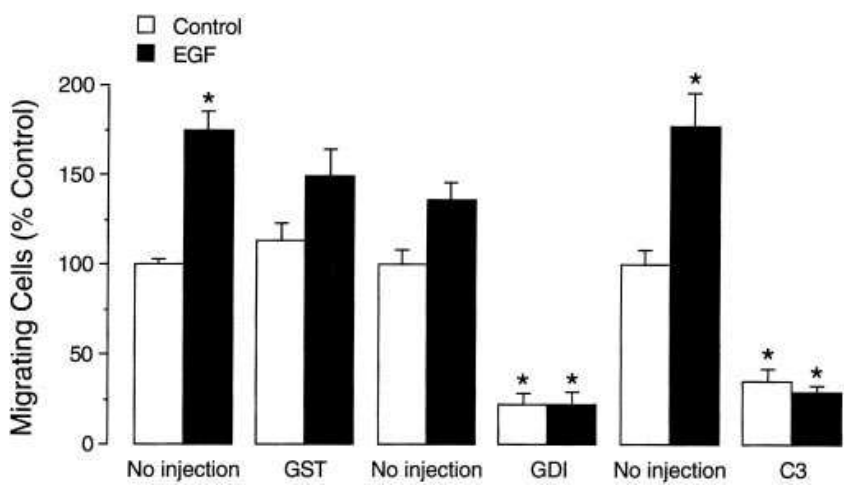

Figure 10. Microinjection of $\mathrm{C} 3$ toxin and Rho-GDI abolished completely the effect of EGF on cell migration. Serum-starved cells $(15 \mathrm{~h})$ were microinjected with $0.3 \mathrm{mg} / \mathrm{ml}$ of either GST, Rho GDI-GST, or $\mathrm{C} 3$ toxin after wounding. EGF $(30 \mathrm{ng} / \mathrm{ml})$ was added to the serumfree medium after the wounding and microinjection. Migration rate was measured at $4 \mathrm{~h}$. Approximately 200 cells were injected per assay. Control cell migration was considered $100 \%$, and data are expressed as percent of control (mean \pm SEM, $n=4)$. *Significant differences when compared to the noninjected group using ANOVA $(P<0.05)$.

Cdc42 proteins are also important in the regulation of Rho during migration of IEC-6 cells, as they certainly are in other cells. In Swiss 3T3 cells, for example, the constitutively activated mutant V12Rac causes the generation of leukotrienes, which in turn induce stress fiber formation. However, leukotriene-dependent stress fiber formation also requires Rho proteins (51). Therefore, in these cells it is likely that Rac acts upstream of Rho in the regulation of stress fiber formation. Moreover, it appears that different events involved in motility are regulated differently by small GTP-binding proteins. For example, in MDCK cells microinjection of the dominant negative A17Rac mutant blocks HGF- and Ras-induced spreading and actin organization, although V12Rac alone does not stimulate either response (44). The upstream regulation of Rho in migrating IEC-6 cells is currently under investigation in our laboratory.

In addition, our findings on the essential role of Rho proteins in intestinal cell migration are important because Rhomodifying toxins are directly involved in antibiotic-associated diarrhea and the potentially fatal form of pseudomembranous colitis. The enterotoxin toxin A and the cytotoxin toxin B, are the virulence factors secreted by $C$. difficile strains that cause these diseases and also induce depolymerization of actin filaments and morphological changes by glucosylation of Rho (24, 25). Hecht et al. (26), using intestinal T84 cells, reported that the organization of the perijunctional F-actin and tight junctions were also affected by toxin A treatment leading to increased epithelial permeability. Corroborating these data, Nusrat et al. (52) reported that in polarized epithelial T84 cells, Rho regulates $\mathrm{F}$-actin distribution preferentially in the apical pole. Our results using unpolarized IEC-6, and polarized Caco-2 intestinal cells show that Rho is important for cell migration in both cell lines. Therefore, we propose that Rho plays an important role in the disease mechanism of pseudomembranous colitis, not only through the regulation of epithelial permeability and barrier function $(26,52)$, but also through affecting cell migration that is essential for the maintenance of epithelial integrity and mucosal restitution.

\section{Acknowledgments}

We thank Dr. Klaus Aktories and Dr. Ingo Just for the $C$. difficile toxins $\mathrm{A}$ and $\mathrm{B}$ and the antibody to $\mathrm{C} 3$ toxin. The authors are thankful to Pat Blanner for his skillful assistance with the experiments and to Danny Morse and Laura Malinick for their help with the figures.

This work was supported by Fundação de Amparo à Pesquisa do Estado de São Paulo (Brazil) through a postdoctoral scholarship to Dr. M.F. Santos and by National Institutes of Health grant DK 37260 (L.R. Johnson) and National Science Foundation-IBN 9321940 (G. Tigyi).

\section{References}

1. Edelman, G.M. 1992. Morphoregulation. Dev. Dyn. 193:2-10.

2. Wang, J.Y., and L.R. Johnson. 1989. Induction of gastric and duodenal mucosal ornithine decarboxylase during stress. Am. J. Physiol. 257 (Gastrointest. Liver Physiol. 20):G259-G265.

3. Silen, W. 1987. Gastric mucosal defense and repair. In Physiology of the Gastrointestinal Tract. L.R. Johnson, editor. Raven Press Ltd., New York. 1055-1069.

4. Quaroni, A., J. Wands, R.L. Trelstad, and K.J. Isselbacher. 1979. Epithelioid cell cultures from rat small intestine. J. Cell Biol. 80:248-265.

5. McCormack, S.A., M.J. Viar, and L.R. Johnson. 1992. Migration of IEC-6 cells: a model for mucosal healing. Am. J. Physiol. (Gastrointest. Liver Physiol. 26):G426-G435.

6. Ridley, A.J., and A. Hall. 1992. The small GTP-binding protein rho regulates the assembly of focal adhesions and actin stress fibers in response to growth factors. Cell. 70:401-410.

7. Hall, A. 1994. Small GTP-binding proteins and the regulation of the actin cytoskeleton. Annu. Rev. Cell. Biol. 10:31-54.

8. Foster, R., K.-Q. Hu, Y. Lu, K.M. Nolan, J. Thiessen, and J. Settleman. 1996. Identification of a novel human Rho protein with unusual properties: GTPase deficiency and in vivo farnesylation. Mol. Cell. Biol. 16:2689-2699.

9. Nobes, C.D., and A. Hall. 1995. Rho, rac, Cdc42 GTPases regulate the assembly of multimolecular focal complexes associated with actin stress fibers, lamellipodia, and filopodia. Cell. 81:53-62.

10. Nobes, C.D., P. Hawkins, L. Stephens, and A. Hall. 1995. Activation of the small GTP-binding proteins rho and rac by growth factor receptors. J. Cell Sci. 108:225-233.

11. Ridley, A.J., H.F. Paterson, C.L. Johnston, D. Dieknam, and A. Hall. 1992. The small GTP-binding protein rac regulates growth factor-induced membrane ruffling. Cell. 70:389-399.

12. Fukumoto, Y., K. Kaibuchi, Y. Hori, H. Fujioka, S. Araki, T. Ueda, A. Kikuchi, and Y. Takai. 1990. Molecular cloning and characterization of a novel type of regulatory protein (GDI) for the rho proteins, ras-p21-like small GTPbinding proteins. Oncogene. 5:1321-1328.

13. Mizuno, T., K. Kaibuchi, T. Yamamoto, M. Kawamura, T. Sakoda, H. Fujioka, Y. Matsuura, and Y. Takai. 1991. A stimulatory GDP/GTP exchange protein for smg p21 is active on the posttranslationally processed form of c-Ki-ras p21 and rhoA p21. Proc. Natl. Acad. Sci. USA. 88:6442-6446.

14. Hiraoka, K., K. Kaibuchi, S. Ando, T. Musha, K. Takaishi, T. Mizuno, M. Asada, L. Menard, E. Tomhave, J. Didsbury, et al. 1992. Both stimulatory and inhibitory GDP/GTP exchange proteins, smg GDS and rho GDI, are active on multiple small GTP-binding proteins. Biochem. Biophys. Res. Commun. 182: 921-930.

15. Podolsky, D.K. 1994. Peptide growth factors in the gastrointestinal tract. In Physiology of the Gastrointestinal Tract. L.R. Johnson, editor. Raven Press Ltd., New York. 129-167.

16. Matrisian, L.M., and B.L.M. Hogan. 1990. Growth factor-regulated proteases and extracellular matrix remodeling during mammalian development. Curr. Top. Dev. Biol. 24:219-254.

17. Thorne, H.J., D.G. Jose, H. Zhang, P.J. Dempsey, and R.H. Whitehead. 1987. Epidermal growth factor stimulates the synthesis of cell attachment proteins in human breast cancer cell line PMC42. Int. J. Cancer. 40:207-212.

18. Yoshida, K.T., T. Tsujino, W. Yasui, T. Kameda, T. Sano, H. Nakayama, T. Toge, and E. Tahara. 1990. Induction of growth factor receptor and metalloproteinases genes by epidermal growth factor and/or transforming growth factor-alpha in human gastric carcinoma cell line MKN-28. Jpn. J. Cancer Res. 81:793-798.

19. Aktories, K., U. Braun, S. Rosener, I. Just, and A. Hall. 1989. The Rho gene product expressed in E. coli is a substrate of botulinum ADP-ribosyltransferase C3. Biochem. Biophys. Res. Commun. 158:209-213.

20. Sekine, A., M. Fujiwara, and S. Narumiya. 1989. Asparagine residue in the Rho gene product is the modification site for botulinum ADP-ribosyltransferase. J. Biol. Chem. 264:8602-8605.

21. Rubin, E.J., D.M. Gill, P. Boquet, and M.R. Popoff. 1988. Functional modification of a 21-kilodalton $\mathrm{G}$ protein when ADP-ribosylated by exoenzyme C3 of Clostridium botulinum. Mol. Cell. Biol. 8:418-426. 
22. Chardin, P., P. Boquet, P. Madaule, M.R. Popoff, E.J. Rubin, and D.M. Gill. 1989. The mammalian G protein rho C is ADP-ribosylated by Clostridium botulinum exoenzyme $\mathrm{C} 3$ and affects actin microfilaments in Vero cells. EMBO (Eur. Mol. Biol. Organ.) J. 8:1087-1092.

23. Paterson, H.F., A.J. Self, M.D. Garret, I. Just, K. Aktories, and A. Hall. 1990. Microinjection of recombinant p21 rho induces rapid changes in cell morphology. J. Cell Biol. 111:1001-1007.

24. Just, I., J. Selzer, M. Wilm, C. von Eichel-Streiber, M. Mann, and K. Aktories. 1995. Glucosylation of rho proteins by Clostridium difficile toxin B. $\mathrm{Na}$ ture (Lond.). 375:500-503.

25. Just, I, M. Wilm, J. Selzer, G. Rex, C. von Eichel-Streiber, M. Mann, and K. Aktories. 1995. The enterotoxin from Clostridium difficile (Tox A) monoglucosylates the rho proteins. J. Biol. Chem. 270:13932-13936.

26. Hecht, G., C. Pothoulakis, J.T. La Mont, and J.L. Madara. 1988. Clostridium difficile toxin A perturbs cytoskeletal structure and tight junction permeability of cultured human intestinal epithelial monolayers. J. Clin. Invest. 82:1516-1524.

27. Lyerly, D.M., H.C. Krivan, and T.D. Wilkins. 1988. Clostridium difficile: its disease and toxins. Clin. Microbiol. Rev. 1:1-18.

28. Knoop, F.C., M. Owens, and I.C. Crocker. 1993. Clostridium difficile: clinical disease and diagnosis. Clin. Microbiol. Rev. 6:251-265.

29. Jalink, K., E.J. van Corven, T. Hengeveld, N. Morii, S. Narumiya, and W.H. Moolenaar. 1994. Inhibition of lysophosphatidate- and thrombin-induced neurite retraction and neuronal cell rounding by ADP ribosylation of the small GTP-binding protein rho. J. Cell Biol. 126:801-810.

30. Bradford, M.A. 1976. A rapid and sensitive method for the quantitation of microgram amounts of protein utilizing the principle of protein-dye binding. Anal. Biochem. 72:248-254.

31. Aktories, K., and I. Just. 1995. In vitro ADP-ribosylation of Rho by bacterial ADP-ribosyltransferases. Methods Enzymol. 256:184-195.

32. O'Farrell, P.H. 1975. High-resolution two-dimensional electrophoresis of proteins. J. Biol. Chem. 250:4007-4021.

33. Self, A., and A. Hall. 1995. Purification of recombinant Rho/Rac/G25k from Escherichia coli. Methods Enzymol. 256:3-10.

34. Leonard, D., M.J. Hart, J.V. Platko, A. Eva, W. Henzel, T. Evans, and R.A. Cerione. 1992. The identification and characterization of a GDP-dissociation inhibitor (GDI) for the Cdc42Hs protein. J. Biol. Chem. 267:22860-22868.

35. Self, A., and A. Hall. 1995. Measurement of intrinsic nucleotide exchange and GTP hydrolysis rates. Methods Enzymol. 256:67-76.

36. Ottinger, M.E., and S. Lin. 1988. Clostridium difficile toxin B induces reorganization of actin, vinculin, and talin in cultured cells. Exp. Cell Res. 174: 215-229.

37. Triadafilopoulos, G., C. Pothoulakis, M.J. O'Brien, and J.T. La Mont. 1987. Differential effects of Clostridium difficile toxins A and B on rabbit ileum. Gastroenterology. 93:273-279.

38. Riegler, M., R. Sedivy, C. Pothoulakis, G. Hamilton, J Zacherl, G. Bischof, E. Consentini, W. Feil, R. Schiessel, J.T. La Mont, and E. Wenzl. 1995. Clostridium difficile toxin $\mathrm{B}$ is more potent than toxin $\mathrm{A}$ in damaging human colonic epithelium in vitro. J. Clin. Invest. 95:2004-2011.
39. Just, I., G. Fritz, K. Aktories, M. Giry, M.R. Popoff, P. Boquet, S. Hegenbarth, and C. von Eichel-Streiber. 1994. Clostridium difficile Toxin B acts on the GTP-binding protein rho. J. Biol. Chem. 269:10706-10712.

40. Dillon, S.T., E.J. Rubin, M. Yakubovitch, C. Pothoulakis, J.T. La Mont, L.A. Feig, and R.J. Gilbert. 1995. Involvement of Ras-related Rho proteins in the mechanisms of action of Clostridium difficile toxin A and toxin B. Infect. Immun. 63:1421-1426.

41. Heri, Y., A. Kikuchi, M. Isomura, M. Katayama, Y. Miura, H. Fujioka, K. Kaibuchi, and Y. Takai. 1991. Post-translational modifications of the C-terminal region of the rho protein are important for its interaction with membranes and the stimulatory and inhibitory GDP/GTP exchange proteins. Oncogene. 6:515-522.

42. Just, I., C. Mohr, C. Habermann, G. Koch, and K. Aktories. 1993. Enhancement of Clostridium botulinum C3-catalyzed ADP-ribosylation of recombinant RhoA by sodium dodecyl sulfate. Biochem. Pharmacol. 45:1409-1416.

43. Garret, M.D., A.J. Self, C. van Oers, and A. Hall. 1989. Identification of distinct cytoplasmic targets for Ras/R-ras and Rho regulatory proteins. J. Biol. Chem. 264:10-13.

44. Ridley, A.J., P.M. Comoglio, and A. Hall. 1995. Regulation of scatter factor/hepatocyte growth factor responses by ras, rac, and rho in MDCK cells Mol. Cell. Biol. 15:1110-1122.

45. Yamamoto, M., N. Morii, K. Ikai, and S. Imamura. 1994. Effect of botulinum C3 exoenzyme on cell growth and cytoskeleton organization in transformed human epidermal cells in culture: a possible role for rho protein in epidermal cells. J. Dermatol. (Tokyo). 8:103-109.

46. Fritz, G., P. Lang, and I. Just. 1994. Tissue-specific variations in the expression and regulation of the small GTP-binding protein Rho. Biochim. Biophys. Acta. 1222:331-338.

47. Gips, S.J., D.E. Kandzari, and P.J. Goldschmidt-Clermont. 1994. Growth factor receptors, phospholipases, phospholipid kinases and actin organization. Semin. Cell Biol. 5:201-208.

48. Stasia, M.J., A. Jouan, N. Bourmeyster, P. Boquet, and P.V. Vignais. 1991. ADP-ribosylation of a small size GTP-binding protein in bovine neutrophils by the $\mathrm{C} 3$ exoenzyme of Clostridium botulinum and effect on the cell motility. Biochem. Biophys. Res. Commun. 180:615-622.

49. Hinsch, K., B. Habermann, I. Just, E. Hinsch, S. Pfisterer, W. Schill, and K. Aktories. 1993. ADP-ribosylation of rho proteins inhibits sperm motility. FEBS Lett. 334:32-36.

50. Takaishi, K., T. Saski, M. Kato, W. Yamochi, S. Kuroda, T. Nakamura, M. Takeishi, and Y. Takai. 1994. Involvement of rho p21 small GTP-binding protein and its regulator in the HGF-induced cell motility. Oncogene. 9:273-279.

51. Peppelenbosch, M.P., R.G. Qiu, A.M. de Vries-Smits, L.G. Tertoolen, S.W. de Laat, F. McCormick, A. Hall, M.H. Symons, and J.L. Bos. 1995. Rac mediates growth factor-induced arachidonic acid release. Cell. 81:849-856.

52. Nusrat, A., M. Giry, J.R. Turner, S.P. Colgan, C.A. Parkos, D. Carnes, E. Leminchez, P. Boquet, and J.C. Madara. 1995. Rho protein regulates tight junctions and perijunctional actin organization in polarized epithelia. Proc. Natl. Acad. Sci. USA. 92:10629-10633. 